\title{
0915. Effect of propofol combined with opioids on guinea pig's small bowel motility in vitro
}

\author{
M Schörghuber ${ }^{1 *}$, E Tatzl $^{1}$, P Holzer ${ }^{2}$, W Toller $^{1}$, S Fruhwald ${ }^{1}$ \\ From ESICM LIVES 2014 \\ Barcelona, Spain. 27 September - 1 October 2014
}

\section{Introduction}

Critically ill patients frequently develop gastrointestinal (GI) motility disorders resulting in feeding intolerance with increased morbidity and mortality. Sedatives and opioids per se have adverse effects on GI motility and can aggravate GI motility disorders.

\section{Objectives}

The aim of this study was to evaluate the inhibitory potency of propofol alone and in combination with remifentanil or sufentanil.

\section{Methods}

Guinea pig's small bowel segments of $8 \mathrm{~cm}$ length were set up in organ baths containing oxygenated Tyrode's solution. Peristalsis was elicited by luminal perfusion $(0.5 \mathrm{ml} / \mathrm{min})$ against an aboral resistance of 400 Pascal (Pa). Perfusion of the segments resulted in an increase of the intraluminal pressure up to a pressure threshold (PT; mean \pm SEM), where peristaltic contractions were triggered. The pressure was recorded at the aboral end of the segments. An increase of the PT was interpreted as an inhibition of peristalsis, while a decrease of the PT was interpreted as a stimulation of peristalsis. A PT of $400 \mathrm{~Pa}$ was equated with a complete block of peristalsis. In a first setting increasing concentrations of propofol $(1 ; 3 ; 10 ; 30$; $100 ; 300 \mu \mathrm{M}$ ) were added to the organ bath and the PT was evaluated at each concentration. These results were compared to increasing concentrations of propofol after pretreatment with sufentanil $(0.1$ resp. $0.3 \mathrm{nM})$ or remifentanil (3 resp. $10 \mathrm{nM}$ ). Statistic calculations were performed using the general linearlized model for repeated measures and the two sided $t$-test of IBM SPSS 21.0.

${ }^{1}$ Medical University of Graz, Department of Anaesthesiology and Intensive Care Medicine, Graz, Austria

Full list of author information is available at the end of the article

\section{Results}

Basic PT without any substances added to the organ bath was $73.83 \pm 5.3 \mathrm{~Pa}$. Propofol had a dose dependent inhibitory effect on peristalsis $\left(\mathrm{p}<0.001\right.$, partial $\mathrm{n}^{2}=0.9$; observed power $=1.00)$. Pretreatment with sufentanil 0.1 $\mathrm{nM}(124.2 \pm 16.1 \mathrm{~Pa} ; \mathrm{p}=0.039)$ and $0.3 \mathrm{nM}(156.2 \pm$ $51.3 \mathrm{~Pa} ; \mathrm{p}=0.04)$ had an additional inhibitory effect at both tested concentrations $(\mathrm{p}=0.041$ resp. 0.029 , figure 1). Remifentanil $3 \mathrm{nM}(97.7 \pm 8.6 \mathrm{~Pa} ; \mathrm{p}=0.49)$ and $10 \mathrm{nM}(304.2 \pm 49.1 \mathrm{~Pa} ; \mathrm{p}=0.005)$ resulted in an increase of the PT compared to basic PT with a slight aggravation of propofol's inhibitory effect $(\mathrm{p}=0.242)$ at low doses and a more pronounced effect at high doses $(\mathrm{p}=0.011$, low vs. high concentration: $\mathrm{p}<0.001$, figure 2 ).

\section{Conclusions}

Propofol and opioids affect neuronal activity via different points of action. While propofol acts on GABA receptors, opioids bind to $\mu, \kappa$ and $\delta$ receptors. In this experimental setting the combination of propofol with opioids shows a more pronounced inhibition of small bowel motility than

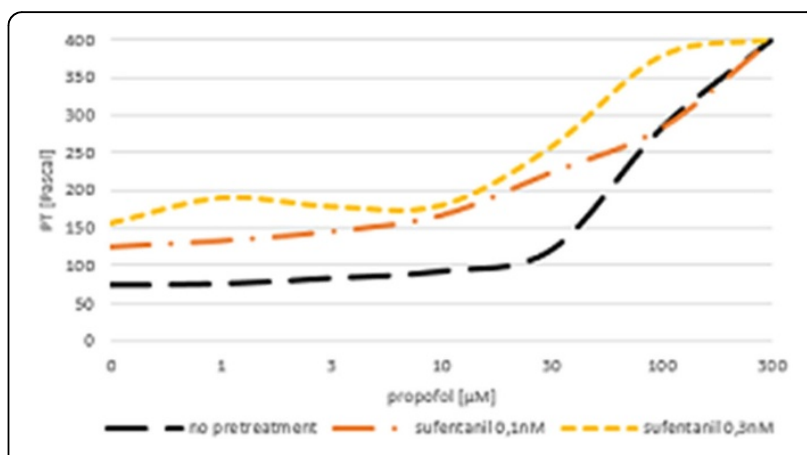

Figure 1 Dose-effect curve of propofol solitary and after pretreatment with sufentanil on guineapig's small bowel motility.

\section{SpringerOpen $^{\odot}$}

(C) 2014 Schörghuber et al; licensee Springer. This is an Open Access article distributed under the terms of the Creative Commons Attribution License (http://creativecommons.org/licenses/by/2.0), which permits unrestricted use, distribution, and reproduction in any medium, provided the original work is properly cited. 


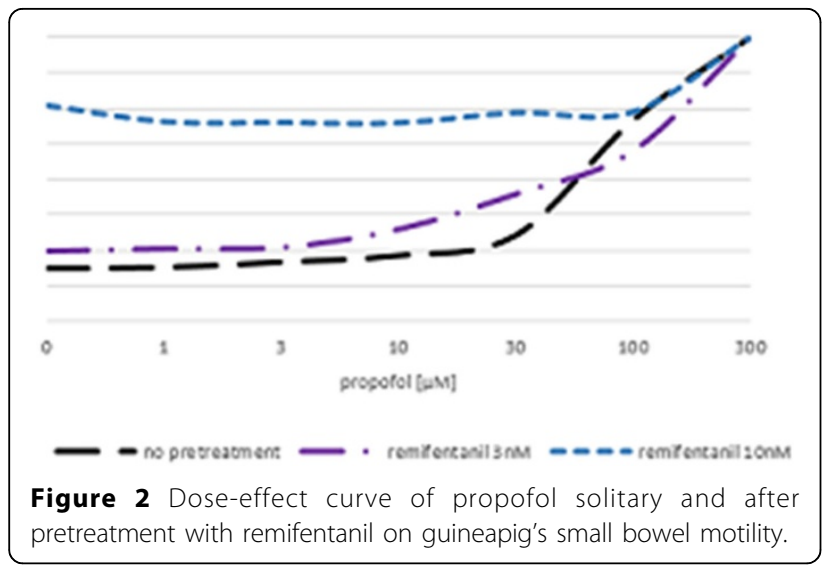

propofol alone. Propofol combined with remifentanil at a high concentration had a pronounced inhibitory effect on peristalsis, while the difference between the two tested concentrations of sufentanil was minor.

\section{Authors' details}

${ }^{1}$ Medical University of Graz, Department of Anaesthesiology and Intensive Care Medicine, Graz, Austria. ${ }^{2}$ Medical University of Graz, Institute of Experimental and Clinical Pharmacology, Graz, Austria.

Published: 26 September 2014

doi:10.1186/2197-425X-2-S1-025

Cite this article as: Schörghuber et al:: 0915. Effect of propofol combined with opioids on guinea pig's small bowel motility in vitro. Intensive Care Medicine Experimental 2014 2(Suppl 1):O25.

\section{Submit your manuscript to a SpringerOpen ${ }^{\circ}$ journal and benefit from:}

- Convenient online submission

- Rigorous peer review

- Immediate publication on acceptance

- Open access: articles freely available online

- High visibility within the field

- Retaining the copyright to your article 